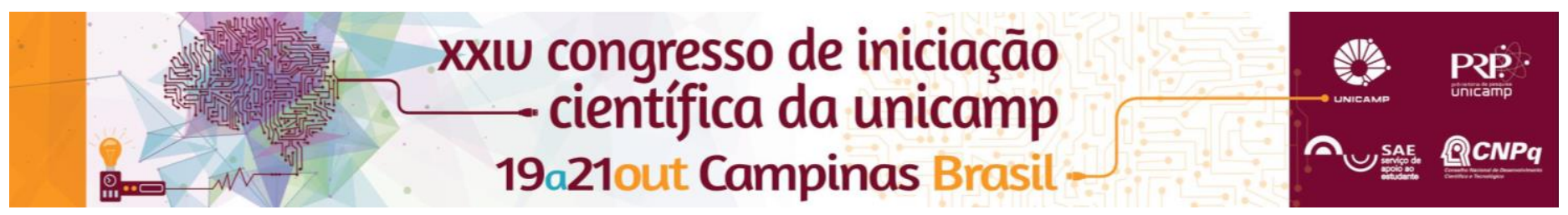

\title{
Trabalho infantil em Limeira - SP: Análise de publicações na rede social - Facebook.
}

\author{
Anderson Souza (IC), Erick Sasse Filho (PQ), Eugênio B. Cassaro Filho (PQ), Márcia Vendramin (PQ), Marta \\ Fuentes-Rojas (PQ), Sandra F.B. Gemma (PQ), Tamires Silva (IC).
}

\begin{abstract}
Resumo
Limeira - SP, cidade localizada no interior de São Paulo, possui um dos maiores polos de produção de semijoias e bijuterias do Brasil e é atualmente conhecida como a "Capital da joia folheada". A utilização de trabalho domiciliar e informal nesta atividade ocorre com frequência, possibilitando o envolvimento de crianças e adolescentes. A pesquisa buscou por meio da netnografia analisar as postagens em um grupo da rede social do Facebook. A análise demonstra a naturalizaçao do uso da força de trabalho neste setor, tanto informal como infantil.
\end{abstract}

\section{Palavras-chave:}

Trabalho infantil, semijoias, Limeira, facebook.

\section{Introdução}

A cidade de Limeira - SP é conhecida atualmente como a "Capital da joia folheada" e dentro deste cenário percorrendo algumas ruas da cidade, independentemente da sua localização, constata-se uma expressiva quantidade de trabalho em domicílio, relacionado com a confecção de semijoias e bijuterias, o que caracteriza um alto nível de terceirização, informalidade, trabalho feminino e infantil'.

O Brasil considera trabalho infantil aquele realizado em idade inferior a 14 anos para qualquer tipo de atividade, sendo que a faixa etária entre 14 a 18 anos é considerada como de trabalho de menor aprendiz, desde que desenvolvido com supervisão e não expondo o jovem a riscos, funções insalubres ou que atrapalhem seu desenvolvimento físico ou intelectual².

Uma pesquisa realizada na cidade de Limeira - SP no ano de 2005 constatou que $27 \%$ dos estudantes (8.340 indivíduos) realizavam trabalhos com semijoias e bijuterias, dentro dos domicílios e considerada como situação de trabalho infantil. A principal atividade desenvolvida estava relacionada com a montagem e soldagem ${ }^{3}$.

Diante destas informações realizou-se a análise das postagens de um grupo no Facebook denominado "Clube da Luluzinha Limeira", por meio da netnografia, que consiste no uso da pesquisa observacional no meio virtual. Este método é composto pelas comunicações mediadas por computador como fonte de dados para chegar à compreensão e à representação etnográfica de um fenômeno ${ }^{4}$.

A cidade de Limeira - SP possui atualmente 296.440 habitantes ${ }^{5} \mathrm{e}$ conforme pode ser observado quase metade da população 122.800 (junho 2016) faz parte como membros. O grupo tem o intuito de divulgar informações sobre a cidade, desde compra, venda, oferta de trabalho, eventos, denúncias, entre outros.

\section{Resultados e Discussão}

A partir dos dados identificados a pesquisa propôs-se a analisar as postagens realizadas neste grupo com o intuito de compreender o mercado de semijoias e bijuterias da cidade. Inicialmente foi definido o período de análise dos dados sendo considerado 01-01-2016 a 3005-2016. Após esta definição realizamos o acesso ao grupo e no campo "Pesquisar neste grupo" digitamos a palavra chave "trabalho, joias" e então o campo visualizar todas as publicações.

A leitura dos posts foi evidenciada principalmente nos que estavam relacionadas à oferta ou procura de trabalho de joias e bijuterias nos domicílios. Outros posts como vendas de produtos e eventos foram descartados.

Em diversos posts é possível identificar o trabalho informal e infantil neste mercado:

"Preciso de meninas que queiram realmente trabalhar com joias e pra trabalhar na minha casa, quem realmente estiver interessado entrar em contato (...)"

"(...) tenho dois filhos precisando urgente de um trabalho, se não for efetivo alguns bicos ou serviço pra fazer em casa, com joia ou qualquer outra coisa, se for preciso vou buscar, obrigado."

"Procuro meninas que tenham responsabilidade, ,compromisso e que consiga produzir 5 mil peças por semana."

"(...) deixando os contados de meu trabalho, pois trabalho de moto táxi, fazemos entregas de serviço em fábricas de joias (...)

A partir destas postagens foi realizada a quantificação destes posts totalizando 210 post publicados durante o recorte da pesquisa, identificando assim uma média de 42 posts publicados mensalmente.

\section{Conclusões}

A cada dia é mais comum a troca de informações através da internet, possibilitando a exposição e a troca de opiniões. Na pesquisa realizada podemos observar a naturalização deste trabalho dentro dos domicílios convocando mulheres, jovens e crianças para o setor informal, podendo estar submissos aos riscos à saúde $\mathrm{e}$ ao seu desenvolvimento. Espera-se com esta pesquisa dar visibilidade desta questão para a indústria e o setor público.

\section{Agradecimentos}

Ao PIBIC, FCA, alunos, monitores e professores que tornaram esta conquista possível.

' FERREIRA, M. A. L. Estudo de Riscos à Saúde dos Trabalhadores ao Meio Ambiente na Produção de Joias e Bijuterias de Limeir - SP. Programa de pós graduação em engenharia de produção. UNIMEP, 2005.

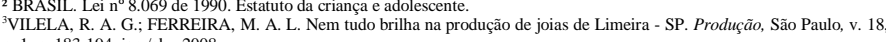
n. 1, p. 183-194, jan./abr. 2008

${ }^{4}$ REAL, V.K.C. Perfis de comunicação política nas redes sociais online: monitoramento e tipologia das conversações nas eleições

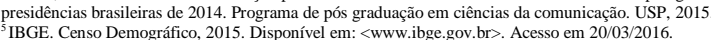

